\title{
THE CULTURAL CHRONICLE AND THE HISTORICAL REALITY OF HALF A CENTURY OF DRAGAN KARADŽIĆ'S CREATIVE
} CATHARSIS

Brankica Bojović, University of Montenegro, Montenegro, brankicaboj@yahoo.com

10.31902/fll.26.2019.16

UDK 75:929Karadžić D.

\begin{abstract}
This study gives an insight into Karadžić's creative work from the aspect of culture and historical reality. It involves a culturological and creative analysis. A review is offered of research on the creative work of this artist in society and his catharsis in various cultural and historical contexts, from the aspect of culture, as a chronicle of society and in terms of pictorial expression. His artistic expression and the semantics of creative interpretation through the chronological method in the research indirectly reveal a cathartic boost given to this artist's steps in his creative expression. The study will be inspirational for chronological approaches regarding creativity in the Balkan cultural area.
\end{abstract}

Keywords: cultural and historical chronicle, Dragan Karadžić, chronological approach, Balkan cultural area.

\section{Introduction}

In this paper, the symbolic elements of Karadžić's paintings and an interpretation of his artistic creative spectrum will be considered from a culturological aspect. In this culturological study, his art exhibitions are evaluated, taking into account the number of them and the content of the reviews about them. The idea of the owner of the Pizzana Art Gallery was to gather this artist's paintings and reaffirm one of the key protagonists of the discipline of art in the Balkan cultural area. The research results were obtained using a multicultural approach, as no scientific results could be obtained without multidisciplinary research that would unite research from many fields. Here a combined approach is used, researching achievements from art history, philosophy, aesthetics, literature and culturology.

With a clear overview of the historical development of Montenegrin painting in the framework of Montenegrin culture and science, an explanation is given of how important tradition is - anthropological and spiritual - as a basis for a special approach to the system of values.

From the aspect of being a chronicle of the society and of contemporary history, the quality of his acrylic paintings, watercolours, drawings and those of 
combined techniques, has lasted into the second decade of the third millennium. Due to three aspects of his personality - those of being an artist of endless talent, educator and creator - the continuity of his work deserves a special attention. The analysis will start from his last exhibition. This study is based on multiple parameters such as reviews by art historians, the statements of various scholars, theory, data collected from introductory speeches, catalogues, monographs and interviews, which summarise the findings about the following aspects of his exhibitions: 1 ) reviews of his exhibition (in terms of the number, content and sources of the reviews); 2) the views of distinguished scholars about his creative work; 3 ) a semiotic hypothesis of signs.

\section{Analysis of Karadžić's Creative Work}

Karadžić's most recent exhibition of paintings was opened by the full academician and President of the Montenegrin Academy of Sciences and Art, Dragan Vukčević, parts of whose inspiring opening speech is reproduced here:

The artist is a messenger who appears to us from the earth's dividing lines. His work is a message which he communicates to us and which can be formed in various different ways. In every age there are only a selected few who can carry this message. There are also not many who can hear and understand it. For this reason, an original work of art is a true miracle. It looks like a fragment of some other world that has fallen into our time period. [...] In our era, which is defined by speed and massiveness, consumption and superficiality, there are fewer and fewer who resemble themselves, and more and more who look no different from others. I won't say that D. Karadžić's paintings are better than the rest fine art theoreticians can provide better testimony to that. What I can say it that, for me, they are different from others.

I experience his pictures as shadows of spirituality. Created in silence and solitude, shaped by his gift and work, they appear to us as windows of their own kind. To those who are able not only to watch but also to see, there appears from them something deeper and Higher than the visible. And it is from that Higher that refined music is heard, which the murmur of time cannot drown out.

This is where the title of the exhibition Traces and Echoes comes from. [...]

[...] these sorts of exhibitions [...] raise many questions. They raise essential questions: what is the calling of the artist nowadays? where do we stand with art in our era? Both questions have their origin in the issue of what today's culture means. From this shadow questions arise about 
continuity, identity and the role of institutions in the era we belong to. The answer requires the dedication of those who create, and the meaningful constancy of those who decide about that creative process.

[...] while a poet is able to recite poetry, while a thinker is able to think, and while a believer is able to believe - mankind will have hope. Events like this one keep the flame of this hope alight. With a sense of gratitude and honour, I declare this exhibition open. (Dragan Vukčević, 29/03/2018)

The exhibition marked 40 years of work by the artist. Art as a means of metaphysical realisation is the personal path of the artist himself, who contributed to the development of painting from the aspect of learning about abstract artists. This academician of the Montenegrin Academy of Sciences and Arts, Dragan Karadžić, is a man with an impressive CV. He was born in Petnjica, Šavnik in 1950. He was a brilliant undergraduate and postgraduate student during his studies at the Faculty of Fine Arts in Belgrade in 1978, in the class of Professor Radenko Mišević. He then specialised at the prestigious Académie des BeauxArts in Paris in the class of Professor Jacques Jankel during 1981-82. He was appointed as a full professor at the Faculty of Arts in Cetinje. He has been on study visits to Italy, Germany, France, Belgium, the Netherlands, Spain, Greece and the United States.

For several years, he worked during the summers on the conservation and restoration of icons and frescoes. In his early youth, he travelled around the whole world and he greatly admired the freedom and beauty of creation something he has not given up even today. A postmodernist and an abstract artist, he is also a pictorial writer who writes his messages using pictorial language and makes his strong impressions even more vivid by using figures of speech such as metaphors and litotes. Karadžić has never disavowed the paintings from his childhood, which he has always carried in his heart.

He has had around 60 independent exhibitions and 400 collective ones. His paintings, watercolours and drawings can be found in 25 museums and galleries, as well as in private collections in Montenegro and most European countries, Israel, Saudi Arabia, China, Vietnam, Japan, Australia, South Africa, Canada and the USA. They are also included in the collections of the Academy of Sciences and Arts in Podgorica, and in the equivalent institutions in Belgrade, Sofia, Bucharest, Beijing, Tirana, Chisinau, Skopje and Banja Luka. Also, his paintings can be found in the rectorates of universities in Podgorica, Moscow, Priština, Niš, Kragujevac and Shkodra, as well as in the collections of 16 universities in Montenegro and the Balkan region.

The first impression one gets at the entrance of his latest exhibition named Traces and Echoes held on 29 March 2018 in the Pizzana Art Gallery in 
Podgorica is that God has already been there and paved the way for humans. The atmosphere produced with the effect of a rainbow after the rain gives a pleasant brightness all around the visitors, scientists, colleagues and cameramen.

While researching the creative process of this Montenegrin academician and his continuity, it became evident that his techniques have their diametrical antipodes. He strongly supported Van Gogh's powerful thesis that no colour has a meaning on its own, unless it has its complement. His mandala symbols appear as domains of lyrical abstraction. The changes in his thinking from his cathartic cleansing and the process of pictorial expression in his paintings originate from the semantic potential of his works. The centre is always in focus, despite the prevailing whiteness, blue or golden-yellow, which recalls the heritage of the Byzantine Empire. The authentic touch of Byzantine golden-yellow space in his most recent paintings marvellously depicts the mosaic of the human soul in Christianity. The golden light is the focal point of his latest painting, which is dematerialised and set as an ideal image of a Christian soul. This is his latest phase, after his previous ones were blue, also of a Byzantine colour, which is often highly valued.

The exhibition of Karadžić's paintings and artistic achievement, which was held in the capital of Montenegro in 2018, is also freshly reviewed by the Montenegrin art historian Ljiljana Karadžić. Two paragraphs of her review are included below. She gave her professional evaluation of his artistry in the following words:

The entire oeuvre of academician Dragan Karadžić is turned toward a delicate feeling for nature and its universal categories. Despite the distant associativity of the landscapes in his artwork, an attentive observer would remark that the relationship the artist has with nature is not merely the transition of experience, the impression of scenery, but rather of transferring into the realm of the painting the rhythm of the ground, air and water that transcend time by following principles which match the philosophy of the East. The thought and feeling of space, both internal and external, transfigures into a new form of visual reality which is outside the physical and the sensual. When taking into account the artist's curiosity of spirit, his reflections, lyrical sensitivity, huge erudition, his interest in music and literature, perfectly woven into his visual art, new contours of the layers and meaning of his art are obtained." (Ljiljana Karadžić, 2018)

Combining research methodologies, analysing his great oeuvre that straddles two different centuries, it can be noted that he has succeeded in maintaining continuity in his Montenegrin tradition, but also in taking his place 
at the top of the Balkan art scene even now in the $3^{\text {rd }}$ millennium. The aim of this study is to improve a culturological approach to the interpretation of his paintings and to initiate research efforts to reconsider his creative impact on the rest of the Balkan region.

The content of his last creative phase recalls Byzantine heritage - his golden-yellow phase finds its complement in his former blue phase. In his earlier works, blue reigned - but not deliberately or intentionally - the colour just happened, like life. He picked blue because it contained the idea of visual natural observation. Blue dominated because of its spatial vastness, it inspired meditation and was a part of the painter's nature. Blue is the colour of the earth, water and sky. He once explained "it is the colour of a hidden place, the space of meditation and memories; it belongs simultaneously to the world and the cosmos" (Personal Interview, Petnica, April 2013). The painter of blue paintings was constantly aligning what was imperishable and universal. Music attracted him within the most sophisticated layers of the mind and played an important role in his creative oeuvre. The indispensable prerequisite in the depths of his soul is music. He once told me that it cleanses a person and gives birth in him to all that is close to the heart, but which can hardly be expressed in words. It is this feeling of a high sense of life that he transmits into the soul of his creative works, like responsiveness to stimulation of the sense of touch. The elements of his creativity are intertwined with his life struggles which made him aware of pain, so closely associated with optimistic light and divine fullness. The content of his artistry is very closely tied to sincerity, mastery as the aesthetic principle of an artist - the revelation of beauty, moral beauty, his unconditional love for Montenegro, which does not diminish his belonging to mankind.

He has been in the field of art for 40 years and he has realised, and still realises, his wide oeuvre at his best and most visited exhibitions, but now in a subtler and more mature way. These are exhibitions that are earning positive reviews from many unbiased and distinguished historians of the arts, philosophers, writers and philologists. Art and the beauty of creation are redefined and revived in the colouring of his calligraphy in which one can perceive the styles of Indian, Japanese and Chinese pictograms. The artist is guided by Picasso's quotation: "I do not create modelled of nature, but like nature. The basic thing of all my creativity is a certain expression from nature transferred into a new visual meaning."

On the other hand, in some of his paintings there were emphasised friezes of the ground, precipitation, ethereal emptiness filled with a calligraphic, musical line which resists decoding, and the upper, cosmic zone can be compared with the replacement of the Greek rhythm of Feast and Fast, which can be resolved one inside the other. With a unique artistic procedure, which is a collection of a number of processes, gestural lines, an expressive and cultivated 
palette, carried out sufficiently fast so that the spontaneity of the manuscript is preserved, but simultaneously, sufficiently focused so that the spontaneity does not harm the culture of painting. His creative work is transparent in formal aspects, but has multiple layers in terms of its content, according to art historian (Ljiljana Karadžić 2018).

Art historians have said that the relevance of an exhibition is often only visible long after the exhibition closes. This is how it was with his exhibition in 2011 held in Belgrade, which was the result of cooperation between the Montenegrin Academy of Sciences and Arts and the Serbian Academy of Sciences and Arts. The content of that regional exhibition was the summarised work of his then almost 40-year-long artistic career. All the works were chosen from his studio as his private belongings. There the colour blue prevailed. He presented universal messages of the perennial Mediterranean, the stunning heights of Durmitor and its green, but also blue, endless hillsides and landscapes. His exhibited works were called associative, lyrical and abstract by various critics. The exhibition consisted of paintings, drawings, watercolours and photographs. The works that were exhibited in the auditorium at the Serbian Academy of Sciences and Arts were the finest selections from his great oeuvre, something that he had never wanted to give up during the four decades of his artistic creativity. The horizon is his beginning, and the foreground then just came about. There, life pulsates in indefiniteness, because through its layers we form images of what happened, what is now, and also signs of what is about to happen as inevitability. He has silently and persistently followed the footsteps of the explorer, far away from fads, convinced that, in the confusing times only strong individual poetics would survive. He brought authentic light into Montenegrin painting, light that shines like a halo from every single painting or creation of his, whether a drawing or a photograph. He wrote and painted everyday environments, which people would pass by without noticing, but when they did, they became the centre of attention and admiration, which went beyond the local and became universal.

Drawing is the framework of all his works, because in each of the four media that the author reluctantly differentiates, drawing seems to be the vertical of the art of painting and the world that it carries within it. In his research Karadžić has dealt with the structure of stone plates, the ground, the horizon, the pictorial language of ancient scripts, the coast, listening to bells, silence and meditation. When this artist listened to the refreshing, cautionary and intoxicating sounds of bells, he would gather everything up and put it on his canvas, to paint that environment of sound, and his wish came true and he created an auditory message in a visual painting. The perception of painting, the associative element of the universal painting language, the abstraction of Karadžićs pictorial language and his depiction of reality make us think about the pictorial and nonverbal as being related in the dynamics of expressive creativity. 
His paintings from the first decade of his career seemed careful and transparent, done by a painter of great skill but in a single note.

The works from the second decade are more profound and harsh-coloured, they lead to calligraphy, in which there can be recognised ancient letters. Sometimes some of them seem to me to originate from India, sometimes from Greece, written down by the hand of a stylist who puts down his writings on a fine painting canvas, where the painter's handwriting takes precedence over script. Karadžić himself says that all those inner silences, turmoils, nightmares and anxieties in him, as well as finding art as a way to escape, are some of the starting points, which can be characterised as more or less the same for all people who deal with art. The differences that make people individuals are essential issues which you can only properly answer if you precisely and persistently dig deep down inside, but also outside of yourself.

Those answers are always written down in sweat and pain, but they also bring the endless joy of creation, the artist explains (Personal Interview, Podgorica, March 2018).

During the third and the fourth decades of his artistic career, life turbulently knocked on the doors of his pictures and he resisted this with great engagement and by using bolder layers of grey, where he could perceive the little clouds of his sister's blessings and soothing stories which entailed messages of peace and love - that we would all gather again at the foot of the green mountains of Durmitor, while the clouds brought tranquillity into the unrest, and vividness into the shadows of the doldrums.

The fourth decade of his career has seen hundreds of pages of artwork written down but also torn up. He was born in Petnica, the place where Vuk Karadžić was also born, so it is no coincidence that he is considered the founder of pictorial scripts, and he writes and uses calligraphy in light blue and traced framed inscriptions for the current and future generations. Therefore, it can be shown that his painting technique is actually a rich calligraphy, inherited from his famous ancestors and that he is a painter who signs in blue, and with pictorial language he brings impressions from nature, life, temporality and seasonal variability to life. At the end of the fourth decade of his career, golden-yellow knocked at his artistic door. Golden-yellow has different connotations depending on the culture, but in his creative oeuvre it is a typical Byzantine colour, where art is considered beauty. In Byzantium, colour was considered to have the same significance as words. Golden-yellow in icons and frescoes had the meaning of the radiant light of God and the splendour of the celestial kingdom where there is no darkness. It symbolised divinity.

Reviewers of visual art refer to Karadžić as the painter of blue paintings, because blue dominates all his pictorial language, but golden-yellow has also dominated in recent years. When I asked him why, he answered that blue domi- 
nates nature, water and air, that green is not even green, but grey-blue in space. Blue is closer to the meditative personality type, and it is also the colour that distinguishes space, it is a spatial colour, interspersed by houses and buildings when viewed from an aeroplane's universal perspective. In answering the question about golden-yellow, he considers that it refers to people inside, an emotional recognition of human spirituality.

Apart from the speech of blue shades and colours, for Karadžić is a typical representative of his movement and lines, which originate from the most ancient scripts, from the tiles into which the writer carved letters. He scratched every single painting and letter, he actually transposed writing as a means of communication into a pictorial language, which was incorporated into deeper and shallower layers on the canvas. He writes, or rather paints, in universal language and his pictures contain much information, and when there are the fewest words and letters in them, then they convey the most. The symbolism of his script immediately attracts one's attention, enhanced by the colour of what is experienced, and if you manage to find messages and scripts in his paintings, then you have really refined the spiritual aspect of your life. There are almost no boundaries in his symbolism, which always, universally, sets into motion the idea of a down-and-out, who is up and then down, but a bit more cautious now, but who then again by means of universal and harmonic colours and words searches for a new quality of life.

It has been shown that an image (or picture) is much more powerful than words, and the artist defines this extraordinarily and leaves us impressed by secret signs beside the road. The power of words is coloured by his hidden inscriptions which revive everyday life; they open up the soul, talking about past and future events. The artistic aspect of pictures and pictorial language is an expression, it is creativity itself. The creative painting process is a means of expression and communication; it is a visual art or total artistic expression. By artistic expression, the author depicted publicly his own vision of what happens in the world around us. His pictorial language represents conscious talents, emotions and contents, which, when put on a canvas or a drawing, lead to the process of individuation and to revived pictures/images in invisible signs and by the visible colours of the planetary aspect of the world in the artist's story.

\section{Distinguished Scholars on Karadžić's Artistic Creativity}

In Dragan Karadžić's paintings, life is depicted in its cycle, as past, present and what is to come. It is all written in a specific script, a language whose alphabet you must first decipher in order to dive into the accumulated semantic empire. From a sociolinguistic perspective, that concept of time can be explained as a process of duration, for the present is the point of contact between the past 
and the future, where the future constantly rewinds and proceeds to the past. Keeping on that line, Ljubomir Gligorijević in 2011 focused on the strength of Karadžić's temperament, artistic concision and fortitude, consistency, determination, professional devotion and morality, saying: "That made me think that, as a visual artist Karadzić, sees more than others and that he differently perceives people, substance, and the universe" (Gligorijević, 2011).

At the exhibition held in Hamilton, Canada in 2001 named "The Mediterranean," he fascinated Fernand Braudel, who wondered:

So, what is the Mediterranean? So many things at the same time. It is not a sea, but a countless number of seas. It is not the sea, but a sequence of seas; it is not a civilisation, but civilisations lying one on top of another. (Fernand Braudel, 2001).

In order to think of his pictoriality as something abstract, Mladen Lompar, an art historian and one of the reviewers of the exhibition of Karadžićs pictures held at the Centre Gallery in Podgorica, wrote that the universality of a close environment and the imaginativeness and suggestion of space are the most extreme points that Karadžić reaches in his painting "transcription." His paintings are not limited spaces of light. Light flows out of them, it spreads by the visualised symphony of nature, defines the inscriptions of the structure that emerge from his memories. As he used to say: "That is where oblivion made a selection," by abstracting and compressing. The basic problem of narration and poetic expression that appears in such endeavours is eliminated by consistently painting facts in the discourse of cryptography. Lompar points out that this is why titles such as Something Mine, To Me, The East of Letter, The Morning Note, Whispering of Space, Whiteness and others are necessary to be able to read the paintings (Mladen Lompar, 1985).

Throughout the structure of the regions of Montenegro, where stone splinters and facets crash against each other, as well as the azure and melancholic sea as the mirror of Baudelaire's man, according to the artist, writes out about the primordial forces of nature and universe, but also he depicts meditations, sorrows, human loneliness and destiny. That is one of the bonding semantic axes of his paintings from different phases which can be marked by landscapes of imagination, because "it is not objects that are painted, but the essence of their appearance" (Nataša Nikčević, 2009: 50).

No matter when a certain painting, sketch on paper or drawing was made, the dialectic cycle of Karadžić's poetic forms include a specific topology of space - "the real space," inside and outside (Henri Michaux, 2011).

The first part is made up of works in which the artist reduces the painting down to values: the surface that finalises 
the explosive spreading to all directions and becomes a powerful flying shape lined with blue abysses and living cursive signs written down with extraordinary vehemence or with slow association to figures, their mysterious linings, coagulation and dissipation. (Zoran Gavrić, 2009)

Regarding the exhibition which we are analysing, I would like to point out the words of the academician Pavle Pejović:

Listening to wise highlanders, [Karadžić] realised that there is also something unknown, which is far beyond the lines of the horizon that was bounded by the two mountains - Durmitor and Vojnik - between which the clear River Komarnica flows like a snake through the Nevidio Canyon. Those earliest paintings of grass and swath, frozen and dry waterfalls, the serenity of the sky and clouds, deep snow and endless whiteness, cut with snow paths, spring pastures and stone daffodils, and the smell of forest raspberries and strawberries, moonlight and sunny days, were left carved in him as a permanent subtext of his creativity, through which he overcame many challenges and answered many issues, but he and we both know that those issues will never provide final answers. (Pejović, 2005)

A former rector of the University of Montenegro, Predrag Miranović (2011), at an exhibition held in Cetinje said:

Looking at the names of his paintings, we sense the unknown special secret of his unique artistic expression. Observing his paintings, we open up the space between the outside and the inside world, fragments and lights, the infiniteness of clearness and the silence of a new solitude. The creativity of our prominent painter lets us follow the traces of spiritual dynamism and the basic creation for constant engaging in the endless space of ideas. In that way, we all become artists and creators of our own cognition and we are especially thankful to Professor Karadžić for that gift.

Kenneth White (2012: 124) describes it in this way:

It turns out that he is one of the most interesting painters that I have ever met, and I have met many of them. Paintings that cover the walls of his studio, and also the ones that he brings out from various heaps are named: Threshold, Things Arrangement, Bright Conscience, Spirit Dynamics, Blue Memories... They are full of energy and light, made up by the parallels, layers, borders and fractures, signs, traces, soundings and light. 
I have picked another strong retrospective review of the painter's work, given by Professor Serge Gaulupeau (2016) who explained his argument precisely, as follows: 1) Certainly, like many others, but still with incomparable animation, the painter is placed into the matchless outfall of the abstract and representative; 2 ) a saturated blue tone characterises many of his paintings, naturally following the examples of many modern European masters along a Cézannian model; 3 ) the power of the lines indicates a vitality which is very common among the most prominent artists of the Adriatic: delineation of areas, division of space, articulation of dynamic places; and 4) last but not least, and almost paradoxically, especially in his watercolours, the cryptographical character of his touch reaches total Oriental refinement (it seems that the reeds of Lake Skadar are not far away...). Because of these, and for other reasons, he finds his own place among great French painters, such as Nicolas de Staël, who was of Russian origin, and Zhao Wuji, born in China, which proves the a priori amplitude of his painting spectrum.

\section{Pictorial Language as Art Signs and Symbols in Semiotics}

Pictorial language is a form of visual communication which, by means of painting symbols and coloured signs and shapes transfers unambiguous information. The painting space represents a general visual picture. Just one painting can be the source of many texts, and just one text or even a paragraph can inspire many painters.

The parallel of comparison between the nonverbal and pictorial is the interpretation of artistic expression through the artist's unique drawings. The artist simultaneously translates one source, whether visual or verbal, into the pictorial environment and the language of coloured letters. The tradition of the accumulated centuries, individual talent and self-contained work make us constantly search for unity in the contradictions and the balance between the captured fragment and the whole.

On a syntagmatic scale of the moving balance of nature, the artist is constantly searching for new patterns and forms of the nonverbal, and yet pictorial context. The deciphering of visual works of art by the pictorial is a one-way road, which sometimes may take a long time to solve -as in the case with the smile of da Vinci's Mona Lisa exhibited at the Louvre in Paris. Time is the best proof of a craft and it integrates the signs into the temporal and spatial context that opens up the archive's vaults and makes the secrets available to everyone.

Curtis Carter examined the pictorial in painting and form in his study called "Painting and Language: A Pictorial Syntax of Shapes". He pointed out that the shapes and forms act like syntactical elements in the language of painting styles. Every single letter shows something concrete or is presented acro- 
nymically in the painting. When the letters are syntagmatically aligned, they make up a set of ideas and are transferred to others. The letters and the thought need to be in a coherent cognitive relationship so as to make the perception of the observer vivid and easier.

By using such pictorial language, an ancient experience is again proved: one should always try to remodel the old person in oneself into a new one, and in a painting we should look for the eternal in the ephemeral. The basic difficulty in the abstract is to recognise the linguistic within other symbolic systems. I would like to point out Carter's approach, which states that painting is a subspecies of pictorial language and that it is rightly considered "the pictorial language of art" in a casual, metaphorical sense. The stimulus for the approach comes from two sources: Pral's theoretical approach to aesthetic analysis and Charles Morris's semiotic hypothesis of signs. Keeping the focus on Carter's study, the following can be pointed out: firstly, it is necessary to mark the domain of the painting language, and the most appropriate domain is painting style. Style is an analogy of language. It has a series of features, including types of shapes and rules for its regulation, along with other syntactical attributes, just like representative semantic aspects, such as an object, a technique and personal embellishment that are carried out by the artist's adaptation.

Carter analyses lines according to direction (horizontal, vertical, straight, corner, crooked or dissected), width and length. He considers them to be pictorial elements expressed through the style of an artist. According to him, shapes and lines in abstract style have less semantic content and more syntactical elements in the pictorial identity. Also, he proved that what is considered pictorial language is actually visual representation along with artist's style, form and lines. Style is pictorial language, and its syntactical elements represent dominant shapes which are used in that style. He has helped greatly in the formulation and descriptive interpretation of pictorial symbols, and his analysis has offered concrete answers to many puzzling issues.

Points of contact can be pointed out between nonverbal and painting. Instances of nonverbal communication can be divided into four categories: aesthetic, physical, semiotic and symbolic, and special attention should be paid to the aesthetic type, because it is expressed through creative expression. It entails music, dance, theatre, crafts, arts, painting and sculpture. Ballet is an excellent instance of aesthetic communication, because it includes both dancing and music, without spoken or sung words. Even while performing opera, which requires the use of words, different facial expressions, costumes, attitudes and gesticulations are used.

The importance of the nonverbal is that aesthetic communication transposes the message of pictorial rhetoric. Painting has found its place in this type of communication, and if observed extra-linguistically, it emphasises a point 
of close contact between painting and communication. Without doubt a solution has been provided in the analysis of the cited authors, so it can be stated that the pictorial language is the aesthetic stylisation of colouration, that is, an aesthetic code which is deciphered within intercultural and multidimensional interaction. Multi-layered, complex and symbolic aesthetic communication is the manifestation of communicative behaviour through the system of the painting technique. The painted message is coded, transposed or transferred into signals, which by different channels from those that decode them, and then semantic contents open up, that could be further semantically analysed.

I will bring this analysis to an end by using the timeless saying "a picture is worth a thousand words."

\section{Conclusion}

This study was based on multiple parameters, such as reviews by art historians, different intellectuals' views, theory, data collected from introductory speeches, catalogues, monographs and interviews, which summarised findings about the following aspects of Karadžić's exhibitions: 1) reviews of his exhibition (in terms of the number, content and sources of the reviews); 2) the views of distinguished intellectuals about his creative work; and 3) a semiotic hypothesis of signs. It has attempted to provide answers to the study's parameters and to effectively evaluate the painting work of one among the most recognised and renowned painters in the Balkans region. A conclusion can be made with the titles of his selected paintings which are in the field of abstraction, but each of them deals with its own visions and the struggles of the artist himself, who overcomes them with his brush on his home terrain. The titles are as follows: Meanings and Pureness, The Letter J, Breakable Note, About the Circle of Loneliness, Slanted Thought, Indulging in an Echo, Garlands, Self-Sown Form, From a Japanese Garden, From the Depths of the Sky, Intertwinings, The Space of Childhood, Uncomfortable in One's Own Skin, From a Map of Traces, Cores, Layers and Dissolution and Heavenly Consolation.

\section{Works Cited:}

Fernand Braudel et al. Memory and the Mediterranean, New York: Alfred A. Knopf, 2001.

Gaulupeau, Serge. Dragan Karadžić „Dodiri i trajanja”, "A Galerija”, Nikšić, 2016. Gavrić, Zoran. "Hofmanove simboličke forme moderne umetnosti”u Gavrić Zoran (priredio i preveo): Werner Hofmann. Studije o umetnosti XX veka, Cetinje, Fakultet likovnih umjetnosti (2005): 11-39 
Gavrić, Zoran. Dragan Karadžić-paintings, drawings, watercolours, Podgorica, Monograph of the Montenegrin Academy of Sciences and Arts, editor Olga Perović, 2008.

Gligorijević, Ljubomir. Dan kada se nebo spustilo na vode, izložba fotografija Dodiri, Podgorica, Centar savremene umjetnosti Crne Gore, 2010.

Goranović, Pavle. Osjećanje vremena i poetika prostora Dragana Karadžića, Bijelo Polje, Galerija Centra za kulturu, 2006.

Karadžić, Ljiljana. Review of the exhibition Dragan Karadžić Traces and Echoes, Art Gallery Pizana, Podgorica, 2018.

Karadžić, Ljiljana. Traces and Echoes, Preface, Podgorica, Pizzana Art Gallery, 2018.

Lompar, Mladen. Predgovor u katalogu Dragan Karadžić-Tragovi prostora, Galerija „Veliša Leković”, Bar, 1985.

Lompar, Mladen. Putovanje kroz svjetlost, Podgorica, Centar savremene umjetnosti Crne Gore, 2007.

Lompar, Mladen. Osavremenjavanje i globalizacija lokalnih osobenosti, retrospektivna izložba u Dvorcu Petrovića u Perjaničkom domu, Podgorica, Centar savremene umjetnosti Crne Gore, 2008/09.

Mahonez, Jeff. "A little bit of Europe downtown", The Hamilton Spectator, Hamilton. 2001.

Maroević, Tonko. Uvodni tekst u Monografskom katalogu Dragana Karadžića "Slojevi pisma obale" slike, crteži, akvareli (2005-2015). Moderna galerija Podgorica, Kotor. Galerija solidarnosti (2015): 5-7

Michaux, Henri. Nouvelles de I'etranger, taken by Zoran Gavrić in "Palimsests by Dragan Karadžić", Podgorica, CANU, paper size A4. (2011): 16-65

Milošević, Ljiljana. Traces and Echoes, paintings, drawings, watercolors, Podgorica, Artspace, Pizana, 2018.

Milošević, Ljiljana. Monografsko izdanje kataloga Tragovi i odjeci. Podgorica, Galerija Pizana. 2018.

Miranović, Predrag. Govor na otvaranju samostalne izložbe Dragana Karadžića, Cetinje. Galerija Fakulteta likovnih umjetnosti 42․ 2011.

Mišević, Radenko. „Dragan Karadžić-Tragovi prostora” Beograd. cat. exh. Salon Muzeja savremene umetnosti, 28. 03-22. 04. 1985.

Nikčević, Nataša. „Lavirint i poetika prostora”, Podgorica, Monitor, 2009.

Pejović, Pavle. Predgovor u katalogu samostalne izložbe, Podgorica. Umjetnički paviljon. 2005.

Perović, Olga. Monografski katalog Dragan Karadžić, crteži, akvareli, fotografije, Crnogorska akademija nauka i umetnosti. Po projektu razmjene akademija CANU I SANU, izložba postavljena u Galeriji SANU, Beograd. (2010):16-17

Perović, Olga. Monograph Dragan Karadžić-paintings, drawings, watercolours, 
Montenegrin Academy of Sciences and Arts, Vol. 62, 2008: 6-267 Vladimir Bonačić and Curtis L. Carter, Painting and Language: A Pictorial Syntax of Shapes, Leonardo, The MIT Press. Vol. 11, No. 1. (1978): 86-87 Vojić, Mirjana. Novović, B. Thunderous Silence of Academician Preface in D.

K. Dragan Karadžić-Vreme sadašnje, Valjevo-Srbija, Internacionalni umetnički studio. 2017.

Vukčević, Dragan. Dragan Karadžić Traces and Echoes, Podgorica. 2018.

White, Kenneth. La carte de Guido, Beograd, Geopoetika. (2012): 124

Yankel, Jacque. Predgovor u katalogu samostalne izložbe u Modernoj galeriji Podgorica. 1983.

\section{KULTURNA HRONIKA I ISTORIJSKA REALNOST POLUVJEKOVNE STVARALAČKE KATARZE DRAGANA KARADŽIĆA}

Studija donosi uvid u Karadžićev stvaralački rad sa aspekta kulture i istorijske realnosti, čime se involvira u jednu kulturološko-kreativnu analizu. Dat je prikaz istraživanja o stvaranju umjetnika u društvu i njegove katarze u raznim kulturno-istorisjkim kontekstima, sa aspekta kulture, društvene hronike i piktorijalnog izraza. Njegov umjetnički izraz, semantika kreativne interpretacije kroz hronološki metod u istraživanju, indirektno otkrivaju katarzičnu nadogradnju stvaraočevih stepenica u kreativnom izrazu. Studija će biti inspirativna za hronološke pristupe u odnosu prema stvaralaštvu na balkanskom kulturnom prostoru.

Ključne riječi: kulturna i istorijska hronika, Dragan Karadžić, hronološki pristup, Balkanski kulturni prostor 